\title{
Muhasebe Meslek Mensuplarının Haksız Rekabet Algıları Üzerine Karaman İlinde Bir Araştırma
}

\author{
Namık Kemal ERDEMİR* \\ Mustafa KAZAK** (D)
}

Öz

\begin{abstract}
Günümüzde muhasebe meslek mensuplarının mesleki faaliyetleri içerisinde karşılaştıkları başlıca sorunlarından biri haksız rekabettir. Çalışmada muhasebe meslek mensuplarının muhasebe mesleğinde haksız rekabet kavram bilgisi, kavramın hukuksal sonuçları ile Türk Ticaret Kanunu (TTK) 4. kısmında yer alan haksız rekabete ilişkin oluşturulan haksız rekabet türleri hakkında bilgi düzeylerini saptama ve haksız rekabet sorununun çözümüne katkı sağlayabileceği düşüncesi ile haksız rekabetin mali nitelikteki uygulamaları ve meslek mensuplarının önerileri çalışmaya dahil edilerek, meslek mensuplarının görüşleri ortaya konmuștur. Araștırmanın verileri nitel analize uygun olarak hazırlanmıș olup, örneklem grubu Karaman ilinde faaliyet göstermekte olan Serbest Muhasebeci Mali Müşavirler içerisinden seçilmiş on beş katılımcıdan oluşmaktadır. Çalışmada nitel araştırma metodu içerisinde yer alan amaçlı örneklem metotlarından biri olan kolay ulaşılabilir durum örneklemesi kullanılmış ve çalışmaya yönelik altı tema belirlenmiştir. Çalışma Nvivo paket programı ile desteklenmiştir. Araştırmanın örneklem grubu ile yapılan görüşmeler gönüllülük esası ile gerçekleștirilmiştir. Araştırmada nitel verilerden elde edilen bulgulara göre, muhasebe meslek mensuplarının haksız rekabet kavram bilgisinin, hukuksal sonuçlarının ve TTK'da yer alan türleri hakkında yeterli bilgiye sahip oldukları tespit edilmiştir. Katılımcıların mali nitelikteki uygulamalarına yönelik ortak tutumu tespit edilmiş olup, haksız rekabet ile ilgili önerileri ayrı bir başlık altında değerlendirilerek sunulmuștur.
\end{abstract}

Anahtar Kelimeler: Rekabet, Haksız Rekabet, Muhasebe, Muhasebe Mesleği.

\section{A Study on Unfair Competition Perceptions of Accounting Professionals in Karaman Province}

\begin{abstract}
It has been tried to determine the level of knowledge of the professional accountants about the concept of unfair competition in the accounting profession, the legal consequences of the concept and the types of unfair competition in the Turkish Commercial Code (TCC). The financial practices of unfair competition and the suggestions of the members of the profession were included in the study and the opinions of the members of the profession were revealed. The data of the research were prepared in accordance with qualitative analysis. The sample group consists of fifteen participants selected from the Independent Accountant and Financial Advisors operating in the province of Karaman.

Convenience sampling, which is one of the purposeful sampling methods, which is a qualitative research method, was used. Six themes were determined for the study. The study was supported by Nvivo package program. According to the findings obtained from the qualitative data in the research, it has been determined that the accounting professionals have sufficient knowledge about the concept of unfair competition, its legal consequences and the types included in the TCC. The common attitude of the participants towards their financial practices was determined and the suggestions regarding unfair competition were evaluated.

Keywords: Competition, Unfair Competition, Accounting, Accounting Profession.

\section{Giriş}

Yasal ve etik olarak özel önem verilmesi gereken bir kavram olan "haksız rekabet", firmaların iç ve dış iş ilişkilerinde yasal ve etik olarak kabul edilebilen davranışları ifade etmektedir. İş davranışı etik olarak, yasa dışı olandan, etik olarak zorunlu olana veya iyi olana kadar uzanan bir çizgi boyunca kategorize edilebilir. Bu sınıflandırma içerisinde tanımlanmış davranışlar, davranışı sergilemesi beklenen firmalar veya grupları bulunabilir. Haksız rekabeti meydana getiren eylemlerin neler olduğu, rekabet hukukunun etik boyutunun yanında, vicdani bir hareket tarzı olup firmaların bilinç düzeyi ile eş güdümlü çalışacaktır. Rekabet açısından ahlaki davranmayan, ancak rasyonel davranış göstermeye çalışan firmalar, rekabet yasası ile tanımlanmıș yaptırımların varlığına rağmen, yasadıșı davranıșın net faydaları nedeniyle, yine de yasadıșı davranışlarda bulunabilirler. Kamu ve özel kesim çalışanlarının gerçekten düşük maaşları, gelir düzeylerini
\end{abstract}

\footnotetext{
* Dr. Öğr. Üyesi, Karamanoğlu Mehmetbey Üniversitesi, nkerdemir@kmu.edu.tr

** Öğr. Gör., Afyonkarahisar Sağlık Bilimleri Üniversitesi, mustafa.kazak@afsu.edu.tr

Makalenin Gönderim Tarihi: 30.12.2020; Makalenin Kabul Tarihi: 02.03.2021
} 
yetersiz bulmaları, verimsiz prosedürler vb nedenlerle rekabet ile ilgili düzenlemelerde yer alan boşluklardan faydalanma yoluyla her ülkede meydana gelebileceği gibi düzenlemelerin yetersiz olduğu veya hiç olmadığı ekonomilerde sıklıkla meydana gelebilmektedir.

Rekabet sürecinde yarışan iki veya daha fazla unsurun bulunması nedeniyle -özellikle beşeri unsurların sürece dâhil olduğu durumlarda- rekabetin olması gereken eksenden çıkması ve etik dış1 müdahalelerin olması rekabet sürecine ilişkin düzenlemeleri gerekli kılmıştır. ABD 1914 y1lında Clayton Anlaşması ile bu konuda öncü olmuştur. Japonya 1947 yllında yürürlüğe giren “Tekel Karşıtı Yasa” ile belki de rekabet ihlallerine ilişkin en ağır yaptırımları tanımlayan ülke olmuştur. Benzer şekilde İngiltere, 1973 y1lında Haksız Ticaret Yasası'nı yürürlüğe sokmuştur. O dönemlerdeki adıyla Avrupa Ekonomik Topluluğu (AET) 1957 yllında kabul edilen ve bir sene sonra yürürlüğe giren "Roma Antlaşması" ile rekabet alanına ilişkin düzenlemelere de yer vermiştir. Birlik bu düzenlemeleri günümüz ekonomik koşulları ve gelişen ticaret ile eş güdümlü şekilde revize ederek uygulamaya devam etmektedir (Ateş, 2008, s. 52). Rusya ise rekabete ilişkin ilk düzenlemeyi 1991 yılında kabul ettiği bir kanunla gerçekleştirmiş, 1993 y1lında Federasyon Anayasası ile rekabeti geliştirmeyi ve haksız rekabet uygulamalarını engellemeyi teminat altına almıştır. 1995 ve 2006 yıllannda yürürlüğe giren iki farklı kanunla düzenlemelerin kapsamını genişletmiş ve ayrıntılı bir tanımlama yoluna gitmiştir (Eryürek, 2020, s. 99). Bu düzenlemeler büyük firmaların pazar davranışlarını, firmaların gizli anlaşmalarını, tedarikçiler ve birlikler arasındaki ilişkileri konu edinmektedir Birçok ülkede yapılan farklı düzenlemeler ile rekabete ilişkin düzenlemeler yapılmakta ve rekabetin sağlıklı bir şekilde gelişmesini olumsuz etkileyecek uygulamalar ve firmalar arası gizli anlaşmalar önceden tanımlanarak engellenmeye çalışılmaktadır. Günümüzde fiyatlandırma kararları ile ilgili etik dış1 uygulamalar, rakipler arası gizli anlaşmalar, ürünlerin içeriği ve miktannda yapılan ve bildirilmeyen gizli ayarlamalar vb. yöntemlerle rekabete yönelik ihlaller gerçekleşebilmektedir. Yapılan düzenlemeler ve bu düzenlemelerde yer alan yaptırımlar çoğu zaman etkili olmakla beraber, yaşanan birçok olumsuz durum bu düzenlemelerin yeterli olmadığını göstermektedir. Özellikle caydırıcı cezaların eksikliği veya cezaların yetersiz oluşu ihlal konusunda vicdani rahatsızlık duymayan firmaları rekabetin ihlal edilmesine yönelik davranışları sergileme hususunda kayıtsız davranmaya itebilmektedir.

Eksikliklerin varlığına karşılık, etik dışı iş davranışlarının etkin bir şekilde tanımlanmasından ziyade genel düzenlemeler yapılmış, bu durum ise rekabet ile ilgili konularda başarı oranı düşük düzenlemelerin yapılmasına rekabet ihlallerinin gözden kaçmasına neden olmuştur. Özellikle kanıtlanmış etik dişı davranışların caydırılmasına yönelik düzenlemeler etkisiz olmuştur. Dahası düzenlemelere rağmen caydırıcı olmayan cezalar yasalar karşısında yaptırımlara razı firmaları kayıtsız davranır hale getirmiştir. İç denetimin yerleşik hale geldiği bankacılık gibi sektörler detaylı denetim faaliyetleri ile diğer sektörlerdeki firmalara göre rekabetçi faaliyetlerde ideal olarak kabul edilebilecek davranışlar sergilemektedir. Dış standartlara yönelik bu tür taahhütler etik sürekliliği kalıcı hale getirebilmektedir. Günümüzde kurumsallaşma çabalarıyla birlikte, firmaların birçoğu da iş sürecinde çalışanların katılımıyla bir bütün olarak şirket içi standartlar belirleyerek etik kurallar silsilesi tanımlamakta ve tanımlanan bu standartlara bağlı kalarak ihlalleri asgari düzeyde tutmaya çalışmaktadır. Ticarete konu edilen mal ve hizmetlerin değişimi ile ilgili sözleşme özgürlüğü çerçevesinde düzenlenen sözleşmeler aracılı̆̆ılyla etik olmayan uygulamaların önüne geçilmektedir. Borçlar Kanunu hükümlerine göre sözleşme taraflannın bir arada olmalanı ve sözleşme üzerinde fikir birliği içinde bulunmaları gerekmektedir. Tarafların ortaya koyduğu irade ve sözleşme hükümlerinin birlikte belirlenmesi genel uygulamada tutarlılığ1 sağlamaktadır. Anlaşmazlıkların olması durumunda tarafların adli mercilere başvurabilmeleri ihtimali, bu sözleşmelerin etik dişı davranışların ve rekabet kurallarını ihlal edecek şartların ihlalini önlemede büyük rol oynadı̆̆ını söylemek mümkündür.

Ahilik gibi köklü geçmişe sahip ve genel uygulama birliğine dayalı yapılarda olduğu gibi geniş kapsamlı düzenlemeler haksız rekabeti engelleme potansiyeline sahiptir. Bu konuda her meslek örgütünün tanımladığ1 standart ve yaptı̆̆1 düzenlemeler en azından meslek mensupları eliyle yapılabilecek etik diş1 ve haksız rekabet yönelik davranısları engelleyebilecektir. Muhasebe alanında da meslek mensuplarının söz konusu eylemleri yapmasını engelleyebilecek düzeyde geniş kapsamlı bir düzenleme mevcuttur. Bu düzenleme ile hem mensupların kendi aralarında sergilemeleri gerekli davranışlan hem de müşterileri ile olması gereken ilişkinin düzeyi açıklanmış ve olumsuz davranışlar engellenmeye çalışılmıştır. 


\section{Literatür Taraması}

Haksız rekabete yönelik birçok faaliyetin odağında pazarlama bölümü çalışanlarının olmasının yanında mali nitelikli işlemler olması nedeniyle özellikle sahip, ortaklar veya yöneticilerin teşvikiyle süreçte muhasebe meslek mensuplarının rolü yadsınamaz. Çalışmada Muhasebe meslek mensuplarında haksız rekabet kavram bilgisi ve haksız rekabet karşısındaki kanuni süreç ve kavram hakkındaki düşüncelerinin yanı sıra haksız rekabet ile ilgili mesleki yönetmeliğe bakış açlarının değerlendirilmesi çalışmanın ana temasını oluşturmaktadır. Bu konuda meslek mensuplarının kavram ile ilişkilerinin değerlendirilmesi üzerine farklı çalıșmalar da bulunmaktadır.

Biyan (2012), çalışmasını 2.740 meslek mensubu üzerinde anket yöntemi kullanarak, muhasebe mesleğindeki mesleki sorunları, hazırlanan sorulara verilen cevaplara istinaden ortaya koymaya çalışmıştır. Çalışma sonucunda ortaya çıkan sonuçlardan birisi de katılımcıların \%98'inin mesleki faaliyetlerinde haksız rekabetin olduğu yönünde görüş bildirmiş olmasıdır.

Ömürbek ve Türkoğlu (2013), çalışmalarını Isparta ilinde faaliyet gösteren 152 muhasebe meslek mensubu ile gerçekleştirmişlerdir. Çalışmanın amacı "muhasebe meslek mensupları arasında ekonomik, sosyolojik, hukuki vb. sorunlardan kaynaklanan haksız rekabetin varlığını ve bu soruna neden olan etmenleri tespit etmek" olarak belirlenmiştir. Çalışma sonucunda meslek mensupları arasında haksız rekabetin varllğını kabul ederek, sorunun en bașta tahsilat olduğunu ve ücret üzerinden yaşanan haksız rekabetin varlığı olduğu yönünde sonuç elde edilmiştir. Bunun yanında bir diğer sonuç ise haksız rekabet sorununun çözümü için mevzuatın yetersiz olduğu yönündedir. Bu durumun muhasebe mesleğini zedelediği çıkan sonuçlar içerisindedir.

Yücel ve Kartal (2014), çalışmalarında İstanbul ilinde faaliyet gösteren 500 muhasebe meslek mensubu üzerinde istatistiki araştırma yapmışlar ve meslek mensuplarının faaliyetlerini gerçekleştirmesinde haksız rekabet ile etik dışı davranışların olduğu sonucuna varılmışır.

Aydemir (2015), "muhasebe meslek mensuplarının sorunları ve çözüme yönelik beklentileri araştırmak" amacıyla 428 muhasebe meslek mensubuna anket uygulamıştır. Analiz sonucunda "mükelleflerin ücretlerini ödememeleri veya düzensiz ödemeleri”, "mesleki yeterlilik ve sorumluluklara karşın muhasebe meslek mensuplarının kazancının düşük olması" meslek mensupları arasındaki en önemli sorunlar olarak ön plana çıkmışır. Katılımcılar meslektaşlarının düşük ücret uygulaması, meslekteki kişilerin hızla artması ile mevzuattaki sürekli ve hızlı değişimin sonucu haksız rekabet oluştuğunu ve dolayısıyla meslekte saygınlı̆̆ın düştüğü yönünde görüş bildirmişlerdir.

Kurnaz, Altunal ve Özbek (2016), Kütahya ilinde faaliyet gösteren 132 meslek mensubu üzerinde anket uygulamış, çalışmada faktör analizi ile "haksız rekabet algısını ve onlanın yazılımla ilgili eleştiri, beklenti ve tutumlarını, haksız rekabeti önlemede E-birlik sisteminin yeterliliğini ve etkinliğini”" ölçmüşler ve çalışma sonucunda uygulamanın meslek mensuplarının işlemlerinde kolaylık sağlayarak, tahsilat sorunlarına çözüm olduğu, iş yüklerinin azalmasını sağladığı yönünde sonuca ulaşılmışlardır.

Kısakürek ve Akarsu (2016), hassas ve önemli bir meslek olan muhasebecilik mesleğinde, mevcut rekabeti ve haksız rekabetin nedenlerini ve boyutlarını ortaya koymak amacıyla, Sivas ilinde çalışan meslek mensuplarına yönelik anket uygulamış olup, meslek içerisinde kısmen de olsa haksız rekabetin var olduğunu ortaya koymuşlardır.

İstanbul Serbest Muhasebeci Mali Müşavirler Odası (İSMMMO) Haksız Rekabetle Mücadele Kurulu Raporu (2018) faaliyet dönemleri içerisinde haksız rekabet ile ilgili yürütülen çalışmaları "Meslek Mensupları Arasında ve İş Sahipleriyle İlişkilerde Haksız Rekabet, Ücret ve Diğer Mali Nitelikteki Uygulamalar ile Haksız Rekabet, Reklam Yoluyla Haksız Rekabet" olarak 3 başlık altında değerlendirmektedirler. Kurul çalışma neticesinde "2018 yllında Yönetim Kurulu kararı ile Haksız Rekabetle Mücadele Kurulu'na sevk edilen dosya sayısını" 1105, "Haksız Rekabetle Mücadele Kurulu Toplam dosya sayısını" 1320 ve "Soruşturması devam eden dosya sayısını" da 369 adet olduğunu belirtmektedirler. Çalışma sonucunda muhasebe mensuplarına zorunlu eğitimin getirilmesi gerekliliği, ücret unsurunun üzerinde durulması ve haksız rekabet koşullarına uymayan muhasebe meslek mensuplarının cezalandırılması gerektiği yönünde önerilerde bulunulmuştur.

Dikmen (2019), Giresun ilinde Serbest Muhasebeci Mali Müşavirler Odasına bağlı muhasebe meslek mensuplarından 40 kişi üzerinde anket uygulayarak "haksız rekabetin varlığını ve haksız rekabet sorununa 
neden olan faktörleri muhasebe meslek mensuplarının mesleki deneyim sürelerine göre ayrıntılı bir şekilde inceleyerek tespit etmek" amacı ile T-testi ve One Way Anova yöntemleri kullanılarak analiz edilmiştir. Analiz sonucunda muhasebe meslek mensuplarının haksız rekabete karşı tutumlarının meslekteki deneyim sürelerine göre değiştiği ortaya konulmuştur.

Arslan ve Kllıç (2020), "Ülkemizde faaliyet gösteren meslek mensuplarının mesleki alanda görülen haksız rekabet uygulamalarının tespiti ve çözümüne yönelik uygulamaların etkinliğine bakış açılarını incelemişlerdir. Ülke genelinde 512 meslek mensubuna uygulanan anket sonucunda meslek mensuplarının konuya bakış açılarında farklılıklar tespit edilmiş ve sorun kayıtsız kalmadıkları ve öneriler geliştirdikleri ortaya konulmuştur.

Karakaya ve Biçer (2020), haksız rekabetin, "muhasebe meslek mensuplarının karşılaştığ1 en önemli sorunlardan olduğu düşüncesi" ile muhasebe meslek mensupları arasında haksız rekabet algisını ölçmek için uzman kişilerle görüşmeler yapmış ve bu görüşmeleri analitik hiyerarşi süreci ile değerlendirilmiştir. Değerlendirme sonucunda meslek mensuplarının sayısının giderek artması, muhasebe meslek mensuplarının mesleklerine gerekli itinayı göstermemeleri, meslekteki mali nitelikli işlemler, ücretlendirme, cezaya rağmen muhasebe ve denetim standartları ile mevzuata uygun hareket edilmemesi, ruhsatların kiralanması, gerçeğe uygun olmayan belge düzenleme, kendi unvanlarının dışında mesleki uygulamalarında farklı unvan kullanmanın haksız rekabete yol açtığı ortaya konulmuştur.

Arslan (2020), "Türkiye'de serbest olarak mesleki faaliyetlerini sürdüren muhasebe meslek mensuplarının muhasebe mesleğinde haksız rekabet sorununun çözümüne katkı sağlayabileceği düşünülen yasal düzenlemeler ve uygulamaların, sorunun çözümünde ne derece etkin olacağına ilişkin değerlendirmelerinin tespit edilmesi ile haksız rekabet sorununun çözümüne yönelik önerilerinin tespit edilmesi" amacıyla Türkiye'nin tüm bölgelerinde Serbest Muhasebeci (SM) ve Serbest Muhasebeci Mali Müşavir (SMMM) unvanlı meslek mensubu olan 512 kişi üzerinde hem nitel hem de nicel yöntemler kullanılarak, nitel verilerin analizinde içerik ve betimsel analiz yöntemi, nicel veriler de ise betimsel istatistik yöntemleri ile bağımsız gruplar T testi (Independent Samples T-Test) tekniği ve tek yönlü varyans analizi (One- Way Anova) tekniği kullanılarak sonuçları değerlendirilmiştir. Sonuçlarda haksız rekabetin oluşmasında "unvan, mesleki deneyim ve yaş değişkenlerinin" anlamlı farkllık göstermediği, "cinsiyet, eğitim düzeyi ve mesleği sürdürdüğü bölge" değişkenlerinin ise analiz sonucunda anlamlı farkllıklar gösterdiği belirtilmiştir.

Aslan Çetin ve Öztürk (2020), yaptıkları çalışmanın amacını "muhasebe meslek mensupları ve çalışanlanı açısından haksız rekabete sebep olabilecek faktörlerin değerlendirilmesini sağlamak" olarak belirtmişlerdir. Çalışmanın uygulaması Kars, Ardahan ve Iğdır illerinde faaliyet gösteren SMMMO'ya kayıtlı muhasebe mensupları ile anket yöntemi kullanılarak yapılmıştır. Sonuç olarak muhasebe meslek mensupları arasında haksız rekabetin yaşandığı görüşü ortaya konulmuştur.

Şendurur ve Çelik (2020), Muş ve Ağr1 ilinde faaliyet gösteren 53 muhasebe meslek mensubunun mesleklerini icra ederken karşılaşılan sorunları belirlemek adına anket uygulamışlardır. Çalışma sonucunda "muhasebe meslek mensupları, daha düşük bir ücretle defter tutan meslektaşlarının olduğunu ve bunun haksız rekabeti doğurduğunu, iş yüklerinin fazla olduğunu ve ücretlerini zamanında alamadıklarını belirtmişlerdir".

\section{Rekabet ve Haksız Rekabet Kavramı}

13/12/1994 Tarih, 22140 Saylı Resmi Gazete'de yayınlanan Rekabetin Korunmas1 Hakkında Kanun'da "Mal ve hizmet piyasalarındaki teşebbüsler arasında özgürce ekonomik kararlar verilebilmesini sağlayan yarışı" olarak tanımlanan rekabet, iş dünyasının vazgeçilmez bir gerçeğidir (Karahan, 2014, s. 23). Aslında sadece beşeri unsurun mevcut olduğu alanlarda değil, doğada her yerde farklı şekillerde karşımıza çıkmaktadır.

Rekabeti ekonominin, mal ve hizmetlerin kalitesinin ve yaşam kalitesinin gelişiminde en önemli unsur olarak kabul eden liberal yaklaşım rekabet yolu ile piyasaların gelişeceğini toplumsal refahın artacağını öngörmektedir (Gürbüz \& Turhan, 2009, s. 62). Toplumsal yaşamda bu ilişkiler -insanlar ve işletmeler arasındaki menfaat ilişkilerinden de kaynaklanan sebeplerle- çoğu kez çatışmaya dönüşmektedir. Çatısmanın çözümünde ise genellikle etik ve yasal kuralların devreye girmesi beklenmektedir (Öz, 2020, s. 
56). Bu noktada haksız rekabet kavramının önemi uygulamada da ön plana çıkmaktadır. Küresel düzenlemelerin yanında ülkemizde de haksız rekabetin önlenmesine ilişkin genel düzenlemelerin yanı sıra mesleki birliklerce hazırlanmış özel düzenlemelerde mevcuttur. 6098 Sayll Türk Borçlar Kanunu'nun "Haksız Rekabet" başlıklı 57. Maddesinde haksız rekabet durumunda mağdur duruma düşen tarafin izleyebileceği yolları açıklanmış ve ticari faaliyetlerden doğan haksız rekabet durumları ile ilgili olarak ise Türk Ticaret Kanunu hükümlerinin saklı olduğu ifade edilmiştir (Özel \& Özdemir, 2017, s. 193 - 194). 6102 Saylı Türk Ticaret Kanunu birinci kitap dördüncü kısımda haksız rekabeti ayrıntılı bir şekilde ele almıştır. Yapılan düzenleme ile rekabet ve haksız rekabetin kapsamı, bütün katılanların menfaatini gözetecek şekilde genişletilmiştir (Ballı, 2015, s.70). Bir filin haksız rekabet olabilmesi için tarafların tacir olmasına, rakip olmasına ve kusurlu olmasına gerek yoktur (Aziz \& Özcan, 2020, s. 4). İmregün (2005)'e göre de haksız rekabet; iktisadi rekabet, aldatıcı veya benzer nitelikli hareketlerle iyi niyet kurallarına aykırı davranış ve rekabet hakkının kötüye kullanılması boyutlarıyla ortaya çıkmaktadır.

Rekabet ilkesine dayanan pazar ekonomisi ile serbest rekabete dayalı bir ekonomi etkin kaynak kullanımını, fiyat istikrarını, payını artırmak isteyen firmaların kaliteli üretim yapmasını sağlar. Böylelikle, ekonominin sürekli ve dengeli gelişmesini sağlanmış olur (Sabır, 2013, s.123). Faaliyetlerde uzmanlaşmanın yanında, yenilikçi yaklaşımlar ile ülkeye birçok anlamda katkı sağlayan rekabet, tekelci anlayışın önüne geçmiş olur. Rekabetin faydalarını sıralamak gerekirse (Arıkan, 2015, s. 15):

a. Verimliliği ve etkinliği yükseltmekte,

b. Kaliteli şekilde hizmet sağlanmasına aracı olmakta,

c. İşletmelerin piyasayı ve teknolojiyi takip ederek alanda yaşanan gelişmelere uyumunu sağlamakta,

d. Organizasyonun düzenli ve dinamik kalmasını sağlamakta,

e. Tekelleşmeyi engellemektedir.

Rekabet toplumun farklı demografik değişkenlere göre birçok kesiminde ve farklı alanlarda karşılaşılan sosyolojik bir olgudur. Bu olgu belirli bir çevrede varlık göstermektedir. Bu çevre bilgi, hizmet ve teknoloji gibi unsurların etkisinde ise rekabetin yaşanması gayet doğal olarak kabul edilmelidir. Bununla birlikte örgütsel açıdan paydaşların farklı amaç ve beklentileri çıkar çatışmalarına yol açmaktadır (Aytar, 2019, s.1962). Bu çıkar çatışmaları da farklı boyutlarda bir rekabet alanı oluşturmaktadır. Bu rekabet ortamı özellikle muhasebe ve denetim disiplinlerinin gözetimine ihtiyaç duymaktadır. Sistemin sağlıklı işleyişi muhasebe meslek mensuplarının davranış biçimlerinin de haksız rekabet konusu açısından ele alınmasını gerektirmektedir. Muhasebe meslek mensuplarının sergiledikleri haksız rekabet davranışları ekonomik sistemin gelişimi ve sürekliliğini olumsuz yönde etkileyerek, mesleki itibar ve güveni de sarsmaktadır. Haksız rekabet; "ana etmenler" ve "diğer etmenler" olmak üzere iki gruba ayrılmaktadır. Bu etmenler (Arı, 2011, s. 66):

- Meslek Mensupları Açısından Haksız Rekabeti Oluşturan Ana Etmenler

- Ücret Açısından Yaşanan Haksız Rekabet

- Tanıtım ve Reklam Açısından Yaşanan Haksız Rekabet

- Meslek Mensupları Açısından Haksız Rekabeti Oluşturan Diğer Etmenler olarak siralanabilir.

\subsection{Türk Ticaret Kanunu'nda Haksız Rekabet Kavramına İlişkin Düzenleme}

TTK'nın 54. Maddesinde haksız rekabet amaç ve ilkeleri tanımlanmış, 55. Maddesinde haksız rekabete aykırı olan hareketler açıklanmıs ve 58. - 61. Maddesinde yapılan haksız rekabetin hukuki sorumluluk boyutu açıklanmıştır. 58. Madde haksız rekabet ile ilgili açılabilecek davaları, 57. Madde sorumlulukları, 58. Madde ise Basın, yayın, iletişim ve bilişim kuruluşlarının sorumluluğunu açıklamaktadır. Madde 60 haksız rekabete ilişkin zaman aşım sürelerini tanımlamaktadır. Madde 61 ise ihtiyati tedbirlerin neler olacağını öngörmüştür. 62. - 63. Maddeler ise ceza sorumluluğunu açıklamıştır. 62. Maddeye göre cezayı gerektiren eylemler açıklanırken, Madde 63’te haksız rekabet eylemini gerçekleştiren tüzel kişiliklerin yaptkkları eylemler nedeniyle, tüzel kişi adına hareket eden veya etmesi gerekmiş olan organın üyeleri veya ortaklan hakkında 62. Madde hükmünce hareket edilebileceği veya tüzel kişi hakkında bunlara özgü güvenlik tedbirlerine karar verilebileceği hükme bağlanmışır (TTK, 55- 63. Maddeleri). 
TTK'nın 55. Maddesi, 54. Madde'de tanımlanan kapsam sınırları çerçevesinde, dürüstlük kuralına ters düşen davranışları ve ticari uygulamaları sıralamıştır. Buna göre(Pınar, 2012, s. 131);

a. Dürüstlük kurallarına aykırı reklam ve satış yöntemleri ve diğer hukuka aykırı davranışlar,

b. Sözleşmeyi ihlale ve sona erdirmeye yöneltmeler,

c. Başkalarının iş ürünlerinden yetkisiz yararlanma,

d. Üretim ve iş sırlarını hukuka aykırı olarak ifşa etme,

e. İşs şartlarına uymama ve

f. Dürüstlük kurallarına aykırı işlem şartlanı kullanma

olarak sıralanmaktadır. Yine bu madde kapsamında ilgili başlıklar detaylıca açıklanmıştır. Muhasebe açısından rekabet ise meslekte mevcut rekabetin belirlenen ilkeler ve yasal zorunluluklar dâhilinde, düzen ve şeffaflık içerisinde, dürüstçe yapılan yarıştır. Rekabetin sağladığı avantajlar (Öztürkler, 2016, s. 5);

a. Düşük fiyat, yüksek kalite,

b. Seçim özgürlüğü,

c. Teknolojik gelişme,

d. Kaynak tahsisinde etkinlik,

e. Artan rekabet gücü,

f. KOBIं

şeklinde özetlenebilir.

\section{Haksız Rekabet ve Muhasebe İlişkisi}

İşletmelerin yaşamını devam ettirebilmesi, pazardan pay almaları, bu payı artırabilmeleri ve kendilerine yer edinebilmelerine kısaca rekabet yeteneklerine bağlıdır (Selçuk vd., 2016, s.203). Rekabet teori ve uygulaması birlikte ele alınarak incelendiğinde sektörlerin ve dolayısıyla genel ekonominin gelissiminin, özellikle toplumsal refahın en önemli koşulu olarak ortaya çıkmaktadır (Karabıçak, 2009, s. 139). Ancak rakipler yasalarda belirtilen davranışları sergileyerek rekabeti aşmak için illegal yollara başvurabilmektedir.

Haksız rekabet sürecinde muhasebe mesleği mensupları da faaliyetleri ile haksız rekabet sürecini destekleyebilmektedirler. Sergiledikleri tutumlar ile mükelleflerinin rakipleriyle girdikleri yarışta haksız başarı sağlamasına aracı olabilecekleri gibi mükelleflerinin sırlanını rakipler ile işbirliği yaparak mükelleflerinin aleyhine gelişebilecek durumlara aracı olabilmektedirler. Yine mesleki özen ve sorumluluk duygusundan uzak bir şekilde faaliyetlerini yürüterek - hata veya hileli işlemlere yol açarak- işletme içi veya dişı çevrelerin menfaatlerini zedeleyebileceklerdir. Örneğin, yanlış raporlanmış bir mâli tablo ile fon sağlama yarışında yatırımcıların mükellef lehine tercihte bulunmasına sebep olabilecektir. Benzer şekilde, meslek mensuplarının kendi aralarında da özellikle müşteri çekebilme adına yapabilecekleri, haksız rekabet olarak belirlenmiş uygulamalar ortaya çıkabilecektir. Bu tarz işlemlerin önüne geçebilmek adına, 21.11.2007 tarih, 26707 Sayll Resmi Gazete'de yayınlanan "Serbest Mubasebeci, Serbest Mubasebeci Mali Müssavir ve Yeminli Mali Müssavirlerin Mesleklerine İlişkin Haksız Rekabet ve Reklam Yasă̆r Yönetmeliğ̈̌" hazırlanmıştur. Bu yönetmelikle, ülkemizde "3568 sayılı Kanuna göre ruhsat almış, Serbest Muhasebeci, Serbest Muhasebeci Mali Müşavir ve Yeminli Mali Müşavirlerin kendi aralarında ve müşterileri ile olan ilişkilerinde haksız rekabetin önlenmesi adına haksız rekabet yapmama yükümlülüğü"

1. "Meslek mensupları arasında ve iş sahipleri ile ilişkilerde haksız rekabet

2. Ücret ve diğer mali nitelikteki uygulamalar ile haksız rekabet

3. Reklam yolu ile yapılan haksız rekabet" olarak üç ana başlıkta toplanmışur.

\section{Yöntem/Analiz}

Araştırmanın verileri nitel analize uygun olarak hazırlanmış olup, örneklem grubu Karaman ilinde faaliyet göstermekte olan Serbest Muhasebeci Mali Müşavirler içerisinden seçilmiş on beş katıllımcıdan oluşmaktadır. Nitel araştırma yöntemi, bağlı bulunulan çevrede toplumsal ve sosyal olayların nedenleri ile birlikte bir bütün olarak ele alıp, gerçekçi sonuçlan hedefleyen bir yaklaşımdır (Yıldırım \& Şimşek, 2011, s. 123 - 148). Çalışmada kullanılan durum analizi yaklaşımı Creswel (2013)'e göre belli bir çerçevedeki olayların ayrıntılı bir biçimde tasvir edilerek incelenmesidir. Çalışmada nitel araştırma metodu içerisinde yer alan amaçlı örneklem metotlarından biri olan kolay ulaşılabilir durum örneklemesi kullanılmıştır. Bu 
metodun tercih edilmesinin başlıca sebebi, araştırmacının araştırmaya katılan kişiler ile aynı şehirde faaliyet göstermesinden kaynaklanmaktadır. Çalışma Nvivo 12 paket programı ile desteklenmektedir. Katulımcıların verdiği cevaplar programla incelenerek nitel çalışma zenginleştirilmiştir. Ayrıca araştırmanın örneklem grubu ile yapılan görüşmeler gönüllülük esası ile gerçekleştirilmiştir.

Görüşme formunu ile katılımcıların haksız rekabet kavramı, kavram hakkındaki düşünceleri, haksız rekabet ile ilgili muhasebe meslek kapsamındaki çıkarllan kanun ve yönetmelikler hakkında bilgileri, haksız rekabetin uygulanmasının hukuksal sonuçları hakkında bilgileri, T'TK 4. Kısmında yer alan haksız rekabete ilişkin oluşturulan haksız rekabet türlerinden muhasebe meslek mensupları içerisinde en çok uygulanan tür/türleri hakkındaki bilgileri, haksız rekabete neden olan mali nitelikteki uygulamaların neler olduğu hakkındaki görüşleri ve haksız rekabetin önlenebilmesi için önerileri bulunup bulunmadığına ilişkin sorular sözlü bir şekilde yöneltilmiştir. Daha öncesinde üç katılımcı ile bir pilot çalışma yapılarak yöneltilen soruların geçerliliğine yönelik bir çalışma yürütülmüştür ve gereken düzeltmeler araştırmacı tarafindan yapılmıştır. Düzeltmeler yapıldıktan sonra katılımcılarla derinlemesine görüşmelerde bulunularak, her bir katılımcı ile ortalama 1,5 saat görüşme gerçekleştirilmiştir. Katılımcılara araştırmanın yapılma amacı açıklanarak, süreç hakkında bilgi verilmiş ve görüşme kuralları ile etik prosedürler kendilerine iletilmiştir. Ayrıca yapılan görüşmelere ilişkin gizlilik taahhüdü verilmiştir. Yapılan görüşmeler katıllmcıların kendi ofislerinde gerçekleştirilmiş ve verilen cevaplar bilgisayar ile kayıt alına alınmıştır.

Verilerin analizi çerçevesinde, yapilmış olan mülakatlar neticesinde elde edilen veri metinleri toplamda 22 sayfadan meydana gelmektedir. Oluşturulan veri metinleri ayrıntılı bir biçimde incelenmiş ve analizi yapılmıştur. Bu aşamadan sonra metinlerde yer alan ifadeler çalışmanın amacına göre irdelenerek, araştırmanın kapsamında yer almayan ifadeler çıkartılmıştır.

\section{Bulgular}

\section{a. Katılımcıların Demografik Özellikleri}

Tablo 1. Araştırma Katılımcılarının Demografik Özelliklerine Yönelik Dağılım Tablosu

\begin{tabular}{|c|c|c|c|}
\hline $\begin{array}{c}\text { Katılımcıların Demografik } \\
\text { Özellikleri }\end{array}$ & $\begin{array}{c}\text { Katılımc1 } \\
\text { Sayıları }\end{array}$ & $\%$ \\
\hline \multirow{3}{*}{$\begin{array}{c}\text { Yaş } \\
\text { Aralığ1 }\end{array}$} & $21-30$ & 3 & 20 \\
\cline { 2 - 4 } & $31-40$ & 3 & 20 \\
\cline { 2 - 4 } & $41-50$ & 6 & 40 \\
\cline { 2 - 4 } Cinsiyet & $51-60$ & 3 & 20 \\
\cline { 2 - 4 } & Erkek & 13 & 87 \\
\hline \multirow{2}{*}{$\begin{array}{c}\text { Öğrenim } \\
\text { Durumu }\end{array}$} & Kadın & 2 & 13 \\
\cline { 2 - 4 } & Lise & 3 & 20 \\
\cline { 2 - 4 } & Lisansäsüstü & 6 & 40 \\
\hline \multirow{2}{*}{$\begin{array}{c}\text { Mesleki } \\
\text { Hizmet }\end{array}$} & 10 yll ve altı & 5 & 33 \\
\cline { 2 - 4 } & $11-20$ yll & 7 & 47 \\
\cline { 2 - 4 } & 21 yll ve & 3 & 20 \\
\hline
\end{tabular}

Tablo 1'de araştırmaya katılan muhasebe meslek mensuplarının 2'sinin kadın ve 13'ünün erkek, \%40'nın 41-50 yaş arasında ve \%47'sinin de meslekte 11-20 yll arasında faaliyet gösterdikleri görülmektedir. Ayrıca katıllmcılanın 6'sı lisansüstü, 6'sı lisans ve 3'ü de lise mezunudur.

\section{b. Araştırmanın Temaları}

$\mathrm{Bu}$ aşamada yarı yapılandırılmış görüşmeler neticesinde araştırma dahilinde temalar belirlenmiştir. Her katılımcıya ait kodlar oluşturulmuştur. Katılımcıların ifadeleri kendi kodlanı içerisinde yer almıştır. Araştırma sonucunda, muhasebe meslek mensuplarının haksız rekabet algısının belirlenmesine yönelik (haksız rekabet kavramı, kavram içeriği, haksız rekabet ile ilgili mevzuat bilgisi, haksız rekabetin uygulanmasının hukuksal sonuçları, TTK 4. kısmında yer alan haksız rekabet türleri ve haksız rekabete neden olan mali nitelikteki uygulamalar) 6 farklı tema belirlenmiştir. 


\section{i. Haksiz Rekabet Kavram Temasi}

Katılımcıların haksız rekabet kavramı ve bu kavramın içeriği ile ilgili bilgiye sahip olup olmadıkları incelenmiştir. Katılımcıların hepsinin haksız rekabet kavramı ve bu kavramın içeriği ile ilgili yeterli bilgiye sahip oldukları tespit edilmiştir.

Tablo 2. Haksız Rekabet Kavram Teması Tablosu

\begin{tabular}{|c|c|c|c|c|c|c|c|}
\hline & \multicolumn{6}{|c|}{ TEMALAR } \\
\hline & & \multicolumn{6}{|c|}{ HAKSIZ REKABET KAVRAMI } \\
\hline & & \multicolumn{6}{|c|}{ KODLAR } \\
\hline & & \multicolumn{2}{|c|}{ Kavram Bilgisi } & \multicolumn{2}{|c|}{$\begin{array}{l}\text { Kavram Hakkında } \\
\text { Düşünce }\end{array}$} & \multicolumn{2}{|c|}{$\begin{array}{c}\text { Kavram } \\
\text { Mevzuat Bilgisi }\end{array}$} \\
\hline & & Yeterli & Yetersiz & Yeterli & Yetersiz & Yeterli & Yetersiz \\
\hline \multirow{15}{*}{ 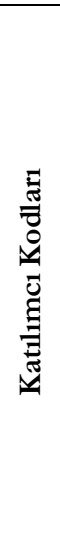 } & K1 & $\sqrt{ }$ & & $\sqrt{ }$ & & & $\sqrt{ }$ \\
\hline & K2 & $\sqrt{ }$ & & $\sqrt{ }$ & & $\sqrt{ }$ & \\
\hline & K3 & $\sqrt{ }$ & & $\sqrt{ }$ & & & $\sqrt{ }$ \\
\hline & K4 & $\sqrt{ }$ & & $\sqrt{ }$ & & & $\sqrt{ }$ \\
\hline & K5 & $\sqrt{ }$ & & $\sqrt{ }$ & & $\sqrt{ }$ & \\
\hline & K6 & $\sqrt{ }$ & & $\sqrt{ }$ & & $\sqrt{ }$ & \\
\hline & K7 & $\sqrt{ }$ & & $\sqrt{ }$ & & $\sqrt{ }$ & \\
\hline & K8 & $\sqrt{ }$ & & $\sqrt{ }$ & & $\sqrt{ }$ & \\
\hline & K9 & $\sqrt{ }$ & & $\sqrt{ }$ & & & $\sqrt{ }$ \\
\hline & K10 & $\sqrt{ }$ & & $\sqrt{ }$ & & $\sqrt{ }$ & \\
\hline & K11 & $\sqrt{ }$ & & $\sqrt{ }$ & & & $\sqrt{ }$ \\
\hline & K12 & $\sqrt{ }$ & & $\sqrt{ }$ & & & $\sqrt{ }$ \\
\hline & K13 & $\sqrt{ }$ & & $\sqrt{ }$ & & $\sqrt{ }$ & \\
\hline & K14 & & $\sqrt{ }$ & & $\sqrt{ }$ & & $\sqrt{ }$ \\
\hline & K15 & $\sqrt{ }$ & & $\sqrt{ }$ & & $\sqrt{ }$ & \\
\hline
\end{tabular}

- "Meslektaşlar arasındaki ilişkileri etkileyen aldatıcı veya dürüstlük kuralına aykırı davranışlardır." K2(03.11.2020)

- "Haksız rekabet bir kişi veya kurumun diğer bir kişi veya kurum üzerinden dürüst olmayan yanıltıc1 ve aldatıcı hareketlerin tamamidir." K9-(05.11.2020)

- "Resmi Gazete Tarihi: 21.11.2007 Resmi Gazete Sayıs1: 26707 ve ayrica 3568 say1l SMMM kanununda ki yönetmeliklerin tamamina vak1fim” K15-(05.11.2020).

15 katılımcıdan sadece 1 kişi haksız rekabet kavramı ile ilgili tam bilgi sahibi değildir. Diğer 14 kişi haksız rekabet kavramı hakkında yeterli bilgiye sahiptir. Haksız rekabet kavram içeriği irdelendiğinde, tüm katılımcıların meslekte haksız rekabetin yapılmasının suç olduğu, mesleğin saygınlığını yitirdiği, yasa ve yönetmeliklerin haksız rekabeti önlemede yetersiz olduğu, haksız kazanç elde edildiği yönünde düşüncelerinin olduğu tespit edilmiştir. Haksız rekabet ile ilgili muhasebe mesleği kapsamında çıkarılan kanun ve yönetmelikler hakkında katılımcıların çoğunluğunun ilgili mevzuat hakkında bilgisi bulunmaktadir.

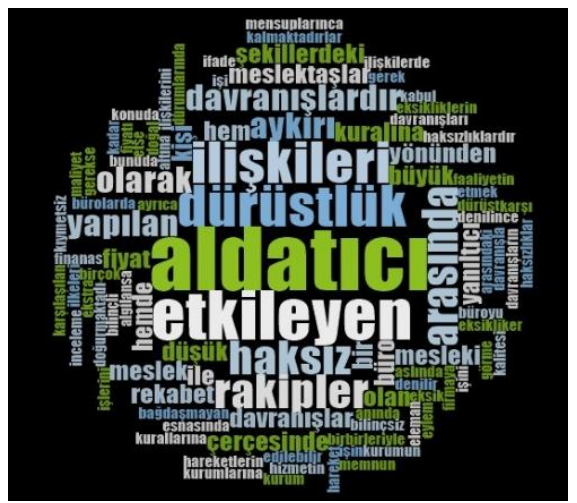

Şekil 1. Haksız Rekabet Kavram Kelime Bulutu 
Katılımcıların haksız rekabet kavramı hakkındaki görüşleri Nvivo 12 programına yüklenerek oluşturulan kelime bulutunda, kavram ile ilgili görüşmecilerin en çok haksız rekabet kavramını aldatma ile bağdaştırdı̆̆ı görülmektedir.

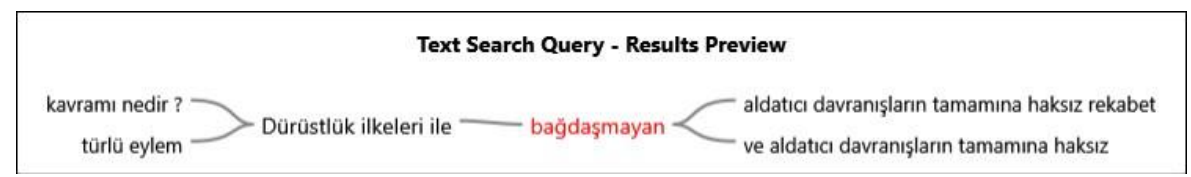

Şekil 2. Haksız Rekabet Kavramı Kelime Ağacı

Programa katılımcıların verdikleri cevaplar yüklenerek haksız rekabet kavramının tanımından elde edilen kelime ağacında da haksız rekabet kavramının dürüstlük ile bağdaşmayan eylem ve kelime bulutunu destekleyen aldatıcı davranış olduğu katılımcıların genel görüşü olarak ortaya konulmaktadır.

\section{ii. Haksız Rekabet Türleri, Hukuksal Sonuçları ve Mali Nitelikli Uygulama Teması}

Katılımcıların TTK'daki haksız rekabet türleri ve haksız rekabet uygulamasının hukuksal sonuçları ile mali nitelikteki uygulamalarla ilgili bilgiye sahip olup olmadıkları incelenmiştir. Katılımcıların çoğunluğunun bu konular ile ilgili yeterli bilgiye sahip oldukları tespit edilmiştir.

Tablo 3. Haksız Rekabetin Hukuksal Sonucu-T'TK'da Yer Alan Türleri Ve Mali Nitelikteki

Uygulamalar Temas1 Tablosu

\begin{tabular}{|c|c|c|c|c|c|c|c|}
\hline & & & & \\
\hline & & \multirow{2}{*}{\multicolumn{6}{|c|}{$\begin{array}{c}\text { HAKSIZ REKABET TÜRLERİ- } \\
\text { HUKUKSAL SONUCU-MALİ NİTELİKTEKİ } \\
\text { UYGULAMALARI } \\
\text { KODLAR }\end{array}$}} \\
\hline & & & & & & & \\
\hline & & \multicolumn{2}{|c|}{ Hukuksal Sonuç } & \multicolumn{2}{|c|}{$\begin{array}{l}\text { T.T.K.'daki } \\
\text { Türleri }\end{array}$} & \multicolumn{2}{|c|}{$\begin{array}{c}\text { Mali } \\
\text { Uygulamalar }\end{array}$} \\
\hline & & Yeterli & Yetersiz & Yeterli & Yetersiz & Yeterli & Yetersiz \\
\hline \multirow{15}{*}{ 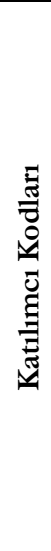 } & K1 & & $\sqrt{ }$ & $\sqrt{ }$ & & $\sqrt{ }$ & \\
\hline & K2 & $\sqrt{ }$ & & $\sqrt{ }$ & & $\sqrt{ }$ & \\
\hline & K3 & & $\sqrt{ }$ & $\sqrt{ }$ & & $\sqrt{ }$ & \\
\hline & K4 & $\sqrt{ }$ & & & $\sqrt{ }$ & $\sqrt{ }$ & \\
\hline & K5 & $\sqrt{ }$ & & $\sqrt{ }$ & & $\sqrt{ }$ & \\
\hline & K6 & $\sqrt{ }$ & & $\sqrt{ }$ & & & $\sqrt{ }$ \\
\hline & K7 & $\sqrt{ }$ & & $\sqrt{ }$ & & $\sqrt{ }$ & \\
\hline & K8 & $\sqrt{ }$ & & $\sqrt{ }$ & & $\sqrt{ }$ & \\
\hline & K9 & & $\sqrt{ }$ & $\sqrt{ }$ & & $\sqrt{ }$ & \\
\hline & K10 & $\sqrt{ }$ & & $\sqrt{ }$ & & $\sqrt{ }$ & \\
\hline & K11 & & $\sqrt{ }$ & $\sqrt{ }$ & & & $\sqrt{ }$ \\
\hline & K12 & & $\sqrt{ }$ & $\sqrt{ }$ & & $\sqrt{ }$ & \\
\hline & K13 & $\sqrt{ }$ & & $\sqrt{ }$ & & $\sqrt{ }$ & \\
\hline & K14 & & $\sqrt{ }$ & & $\sqrt{ }$ & & $\sqrt{ }$ \\
\hline & K15 & $\sqrt{ }$ & & $\sqrt{ }$ & & $\sqrt{ }$ & \\
\hline
\end{tabular}

- “Bu konuda bilgim yok." K11-(05.11.2020)S.4.

- “İş sırlarını ifşa etmek, İş şartlarına uymamak, dürüstlük, fiyat” K11-(03.11.2020)S.5.

- "Bağımsılık ilkesine göre objektif uygulanmayan mesleki faaliyetler (işletmenin taraflarına karsı sosyal sorumluluktan ziyade vergi ve yasal hükümlülük uygulamalıdır) Kamu etkinliği sağlanmalı.” K1(03.11.2020)S.6.

Haksız rekabetin uygulanmasının hukuksal sonuçları hakkında genel itibari ile katılımcıların yeterli bilgisi bulunmaktadır. TTK 4. Kısmında yer alan haksız rekabete ilişkin oluşturulan haksız rekabet türlerinden muhasebe meslek mensupları içerisinde en çok uygulanan tür/türleri hakkında 13 katılımcının bilgi düzeyi yeterli olup, 2 katılımc1 yeterli bilgiye sahip değildir. 


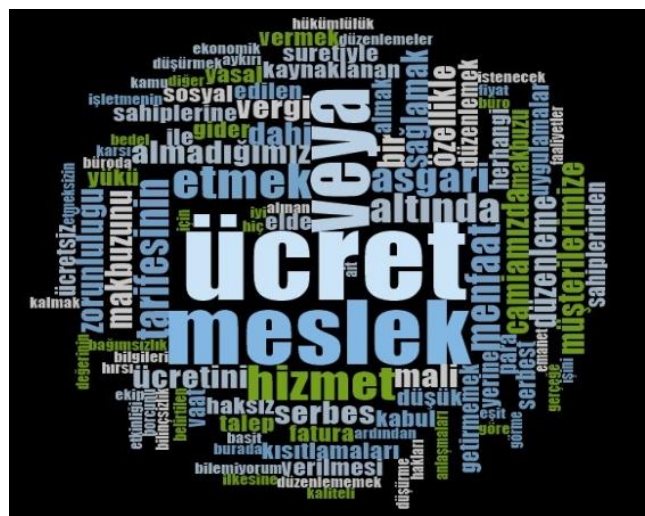

Şekil 3. Haksız Rekabete İlişkin Mali Nitelikteki Uygulamalara Ait Kelime Bulutu

Haksız rekabete neden olan mali nitelikteki uygulamalara ilişkin katulımcılar yeterli bilgi düzeyine sahip olmakla birlikte, katlımcıların çoğunluğu meslektaşlarının düşük ücret tarifesi uygulayarak, hatta bedelsiz iş yapılması sonucu haksız rekabet koşullarının sağlandığı görüşünü savunmaktadır. Bu durum Nvivo 12 programında katıllımcıların verdiği cevaplara istinaden oluşturulan kelime bulutunda da ücret kelimesi ile desteklenmektedir. Katılımcılar mali nitelikteki uygulamanın meslektaşları arasındaki en önemli sorunun ücret tarifesindeki sıkıntılar olduğunu özellikle vurgulamaktadırlar.

\section{Tartı̧̧ma ve Sonuç}

Çalışmada elde edilen bulgular sonucunda, kavram bilgisine yönelik haksız rekabet kavram temaları dâhilinde; katılımcıların haksız rekabet kavramı ve kavramın içeriği ile ilgili yeterli bilgiye sahip oldukları görülmektedir. Ayrıca haksız rekabet kavramı ile ilgili mevzuat bilgisi hakkında 8 katılımcının yeterli ve 7 katılımcının da yetersiz olduğu belirlenmiştir. TTK 54 üncü maddesi, bütün katılanların menfaatine, dürüst ve bozulmamış rekabetin sağlanması amacıyla tanımlamalar yaparak, rakipler arasında veya tedarik edenlerle müșteriler arasındaki ilişkileri etkileyen aldatıcı veya dürüstlük kuralına diğer şekillerdeki aykırı davranışlar ile ticari uygulamalar haksız ve hukuka aykırı olduğunu hükme bağlamıştır. (TTK, 54). Katllımcıların kavram hakkında verdikleri cevaplar doğrultusunda kelime bulutunda "aldatıcı" kelimesi katılımcılar tarafından ön plana çıkartılmaktadır. Kavram hakkında bilginin bu denli bilinmesinin nedeni, mesleklerini icra ederken haksız rekabete maruz kaldıklarını düşünmelerinden kaynaklandığı söylenebilir.

Haksız rekabetin uygulanmasının hukuksal sonuçları hakkında genel itibari ile katılımcıların yeterli bilgisi bulunduğu, TTK 4 . Kısmında yer alan haksız rekabete ilişkin oluşturulan haksız rekabet türlerinden muhasebe meslek mensupları içerisinde en çok uygulanan tür/türleri hakkında ise 13 katılımcının bilgi düzeyinin yeterli olduğu ve 2 katılımcının bilgi düzeyinin de yetersiz olduğu belirlenmiștir. Katılımcılar haksız rekabete neden olan mali nitelikteki uygulamalara ilişkin yeterli bilgi düzeyine sahip olmakla birlikte, çoğunluğun düşüncesini meslektaşlarının düşük ücret tarifesi uygulayarak, hatta bedelsiz iş yapılması sonucu haksız rekabet koşullarının sağlandığı görüşü oluşturmaktadır. Nvivo 12 programında katilımcıların verdiği cevaplara istinaden oluşturulan kelime bulutunda da ücret kelimesi ön plana çıkarak, katllımcıların mali nitelikteki uygulamada meslektaşlanı arasındaki en önemli sorunun ücret tarifesindeki sıkıntılar olduğunu özellikle vurguladıkları söylenebilir. Bunun yanı sıra katılımcılar haksız rekabet yapılması sonucunda mesleki itibarlarının da zedelendiği yönünde görüş belirtmektedirler.

Serbest piyasa ekonomisinde aynı sektörde bulunan firmalar arasında ticari bir rekabetin bulunması tüm paydaşlar açısından faydalı bulunmaktadır. Bu rekabet müşteriler, tedarikçiler, devlet ve ekonomi açısından gelişimin ve kalitenin tetikleyicisi olarak işlev görmektedir. Rekabet sürecinin olumlu etkisi tüm paydaşlar tarafından hissedilmektedir. Statik ve standart yapılar daha dinamik ve yenilikçi yapılara dönüşmektedir. Tüm bu süreçlerin sağlıklı işlemesi ve olumlu etkilerinin yansıması sağlıklı bir yasal zemine gereksinim duymaktadır. Dolayısı ile belirli bir ekonomik sistemde sermaye hareketliliği, ticari işlemler ve rekabet konusu tüm paydaşların menfaatlerini koruma yetki ve kapasitesine sahip olmalıdır. Firma ve bireylerin rekabet özgürlükleri yasal zemin çerçevesinde korunmalıdır. Günümüzde Ticaret Kanunu, Borçlar Kanunu ve Haksız Rekabet Kanunu taraflar arasında yaşanabilecek ihlal, aldatma ve anlaşmazlıklara yönelik etkin 
çözüm önerileri sunan hükümler içermektedir. Bu kapsamda muhasebe meslek mensuplarının haksız rekabet algıları ve farkındalıkları sistemin sağlıklı işleyişi açısından önemli bir işleve sahiptir.

İş dünyasının faaliyetlerini yürütürken işin doğasında olan rekabetin ahlak, meslek ve hukuk kurallarına uygun bir şekilde yapılması ve haksız rekabete yol açacak fiil ve davranışlardan uzak durulması gerekmekte ve bu doğrultuda hareket edilmesi beklenmektedir. Yasada tanımlanmıs veya tanımlanmamasına rağmen toplumsal kabul ve teamül haline gelmiş hareket rekabeti ve bu süreçte sergilenecek tavırları şekillendirecektir. Yasa ve yönetmeliklerde belirlenmiş olan sınırlar içerisinde kalmak, rekabette etik davranılmasını sağlayacaktır. Örneğin, "kötüleme" fiilini işlemek, gerçek dışı veya yanıltıcı açıklamalarda bulunmak, hukuki olmayan yollarla üçüncü kişiyi rekabette öne geçirmek, çeşitli belge ve sertifikalara sahip olmadığı halde sahipmişçesine davranmak, karıştırılmaya yol açan önlemler almak, rakibi gereksiz yere kötülemek, gereksiz yere rakibin tanınmısslığından yararlanmak, müşterileri yanıltmak amacıyla tedarik fiyatının altında satış yapmak, ek edimler ile sunumun gerçek değeri hakkında yanıltmak, saldırgan satış yöntemleriyle müşterinin karar verme özgürlüğünü sınırlamak gibi hususlardan ticari faaliyetlerde kaçınmak gerekmektedir.

Katıllımcılarla yapılan görüşmede, kendilerine son olarak haksız rekabetin önlenebilmesi için görüş ve önerileri sorulmuştur. Genel itibari ile katılımcılar;

- Ücret konusuna dikkat çekmekte olup, mükelleflerinden tahsil etmedikleri/edemedikleri ücretler için makbuz düzenleme zorunluluğunun kaldırllması gerekliliğini belirtmişlerdir.

- Diğer bir husus ise vergi yükü olarak belirtilmiş ve serbest meslek uygulamasında KDV indirimi yapılarak, KDV'nin \%8 oranına çekilmesi olarak belirtilmiştir.

- Katılımcilar, mükellefler tarafindan ücretlerin ödenmemesi durumunda odaların gerektiğinde ücretlere müdahil olması gerektiği, ücret yönetmeliğinin düzenlenmesi ve haksız rekabetin önlenmesinde ücret konusuna hassasiyet gösterilmesi gerektiğini belirtmişlerdir.

- Haksız rekabetin oluşmaması adına kamu denetiminin arttırılması ve haksız rekabetin önlenmesi adına mevzuatın genişletilmesi yönünde görüşler bulunmaktadır.

- Bu konuda meslek içi eğitimlerin arttırılması gerektiği vurgulanarak, eğitimlerin ücretsiz olması yönünde öneriler bulunmaktadır.

- Mesleği icra edenlerin etik ve ahlaki ilkeler doğrultusunda, mesleki dayanışma içerisinde bilgi paylaşımı ve iletişimin kuvvetlendirilmesi gerekliliği savunulmuştur.

Muhasebe mesleği, kayıt dışı ekonomi ile mücadelede hayati bir role sahiptir. Bu nedenle meslek mensuplarının haksız rekabete yönelik uygulamalara hassasiyet gösterecek meslek gruplarının başında olması gereklidir. Bu amaçla, tanıtım faaliyetlerine yönelik reklam ve rekabet yasağının mesleğe özgü bir yönetmelikle düzenlenmiş olması haksız rekabetin önüne geçme noktasında oldukça önemlidir. Yönetmelikte rekabet denilince akla gelen ilk konu olan ücret konusunun düzenlenmiş olması yerinde bir karar olmakla birlikte, özellikle dijital uygulamaların mecburi sebeplerle bile olsa hayatın her aşamasına girmiş olduğu bu dönemde, haksız rekabeti önleyici elektronik denetim mekanizmalarının mevcut olanlarının etkinliğinin artırlmasının yanı sıra yeni düzenlemelerin tesis edilmesi yerinde bir uygulama olacaktır.

Haksız rekabeti önlemeye yönelik olarak mevcut denetim uygulamalarının yeterliliğinin meslek mensuplannca algılanma biçimi, yerleşik uygulamalann eksik yönleri ve nasıl geliştirilebileceğinin araştırıldığ1 çalışmaların yanı sıra mesleğe yönelik bilişim tabanlı, anında tespit ve takibin yapılacağı uygulamaların araştırıldığı çalışmalar mesleğe önemli katkılar sağlayacaktır.

Haksız Rekabet ve Reklam Yasağ1 Yönetmeliği, hangi unvana sahip olunursa olsun, "meslek mensuplarmin kendi aralarnda ve müșterileri ile olan ilișkilerinde baksiz. rekabetin önlenmesi, dürüst ve bozulmamıs rekabetin sağlanmast ve meslek. mensuplarmm is elde etmek, için reklam saynlabilecek, eylem ve işlemlerinin kapsam, simir ve esaslarnmn belirlenmesine yönelik”" (Md.1) kapsamlı bir düzenlemedir. Ancak iç ve dış paydaşlarına yönelik olarak bilgi üreten, varlık ve kaynak dengesini ve bunların verimli değerlendirilmesini sağlayan, ülke ekonomisini etkileme düzeyi yüksek, hayati bilgiler üreten bir mesleğin uygulayıcılarının bu yönetmelik dışında hata ve hilelerden arındırılmış bir muhasebeleştirme sürecini yürütmeye istekli olacak şekilde motive edilmesi gereklidir. Anılan yönetmelik haksız rekabet olarak belirlenen durumları üç başlık altında 
sınıflandırarak detaylandırmıştır. Bu anlamda yeterli olmakla birlikte yönetmeliğe aykırı fiillere yönelik caydırıcılı̆̆ın artırılması büyük önem arz etmektedir.

Ekonomik kaygılar veya başka nedenlerle meslek mensuplarının yanında, toplum tarafindan da müşterilerin işveren, muhasebecilerin ise her talimatı uygulamaya hazır iş görenler olarak görüldüğü bir alg1 hâkimdir. Mevcut alg1, "Vergi" eksenli problemler başta olmak üzere, gizli düşük ücretlendirme, müşteri kazanma rekabeti, tahsilat sürecinde yaşanan sorunlar ve müşteri kaybetme endişesi nedeniyle mali danışmanlık dışında kalan iş tanımı içerisinde yer almayan görevlerin üstlenilmesi gibi sorunları beraberinde getirmektedir. $\mathrm{Bu}$ algiyı ortadan kaldıracak düzenlemelerin yapılması mesleğin itibarının artırılmasında, meslek mensupları arasında haksız rekabetin önlenmesi ve meslek mensuplarının yol açacağı etik dışı davranışların engellenmesinde stratejik öneme sahip bir konudur.

\section{Extended Abstract}

"Unfair competition", which requires special attention legally and ethically, is the behavior that can be accepted legally and ethically in the internal and external business relations of the companies. Article 54/2 of the TCC defines unfair competition as "Deceitful or other forms of violation of the integrity rule and commercial practices that affect the relations between the suppliers and the customers are unfair and unlawful." In terms of accounting, competition is an honest race held in order and transparency, within the principles of the current competition in the profession and legal requirements. On the contrary, the inappropriateness of the actions of the accounting professionals will increase unfair competition and cause economic problems.

The main theme of the study is to evaluate the opinions of the members of the profession on the concept of unfair competition and the legal process against unfair competition, as well as their perspective on the relevant professional regulation. The data were prepared in accordance with qualitative analysis, and the sample group consists of fifteen participants selected from the Independent Accountant and Financial Advisors operating in the province of Karaman. In the study, convenience sampling, which is one of the purposeful sampling methods with the situation analysis approach, was used and supported by Nvivo 12 package program.

With the interview form, the participants opinions on the concept of unfair competition, their opinions about the concept, their knowledge about the laws and regulations issued within the scope of the accounting profession related to unfair competition, their information about the legal consequences of the application of unfair competition, among the accounting professionals from the types of unfair competition created in the 4th part of the TCC. The questions regarding the information about the most applied species / types, the opinions about the financial practices that cause unfair competition and whether there are suggestions to prevent unfair competition were posed verbally. The created data texts were examined in detail and analyzed.

2 of the accounting professions participating in the study are female and 13 are male, $40 \%$ are between the ages of $41-50$ and $47 \%$ are active in the profession for 11-20 years. In addition, 6 of the participants are graduate, 6 are undergraduate and 3 are high school graduates and most of them (14 participants) have sufficient knowledge about the concept of unfair competition. In the word cloud, it is seen that the participants related to the concept mostly associate the concept of unfair competition with deception.

It was examined whether the participants had knowledge about the types of unfair competition in the TCC and the legal consequences of unfair competition practices and financial practices. It has been determined that most of the participants have sufficient knowledge on these issues.

Participants generally have sufficient knowledge about the legal consequences of the application of unfair competition. Participants particularly emphasize that the most important problem among colleagues of the financial practice is the problems in the wage scale.

The Unfair Competition and Advertising Prohibition Regulation, regardless of the title, "to prevent unfair competition, to ensure honest and intact competition, and to determine the scope, boundaries and principles of the actions and transactions of the members of the profession that can be considered as advertisement in order to obtain jobs"(Art.1) is a comprehensive regulation. However, the practitioners of a profession that produces information for its internal and external stakeholders, ensures the balance of 
assets and resources and their efficient evaluation, produces vital information with a high level of affecting the country's economy, should be motivated to be willing to carry out an accounting process that is free from errors and frauds outside of this regulation.

There is a prevailing perception that customers are seen as employers and accountants as employees who are ready to implement every instruction, besides that by the society, as well as by the members of the profession for economic or other reasons. The current perception brings with it problems such as "tax"-based problems, hidden low pricing, competition for gaining customers, problems in the collection process and undertaking tasks that are not included in the job definition except financial consultancy due to the concerns of losing customers. Making regulations that will eliminate this perception is a strategically important issue in increasing the reputation of the profession, preventing unfair competition among professionals, and preventing unethical behaviors that will be caused by members of the profession.

\section{Kaynakça}

Ar1, H. (2011). Kurumsallaşma sürecinde haksız rekabet. 3. Türkiye Haksız Rekabet Kongresi Bildirileri İcinde (s.66 - 71). TÜRMOB Yayınlarn 412.

Arrkan, Y. (2015). Medeniyet, "haksız rekabet" ve ortak gelecek muhasebe. ISSMMMO Mali Cöž̈m Dergisi, (127), 9-16.

Arslan, Ü. (2020). Mubasebe mesleğinde haksız rekabetin boyutu: Türkiye'de mubasebe meslek mensuplarna yönelik. bir araștırma. Yayımlanmamış Doktora Tezi, Karabük Üniversitesi İşletme Anabilim Dalı, Karabük.

Arslan, Ü., \& Kilıç, M. (2020). Muhasebe mesleğinde haksız rekabetin boyutu: Türkiye'de muhasebe meslek mensuplarına yönelik bir araştırma. Sosyal Bilimler Araştırmalar Dergisi, 15(1), 205-218. https://dergipark.org.tr/tr/pub/gopsbad/issue/55182/689401.

Aslan Çetin, F., \& Öztürk, S. (2020). Muhasebe meslek mensupları ve çalşanlar açısından haksız rekabet. Karadeniz Uluslararast Bilimsel Dergi, (46), 199-219. doi: 10.17498/kdeniz.689191.

Ateş, M . (2008). Son yapılan düzenlemeler ışı̆̆ında AB rekabet hukuku ve politikasına genel bir bakış. Ankara Avrupa Calssmalarn Dergisi, 7(2), 47-76. doi: 10.1501/Avraras_0000000124

Aydemir, O. (2015). Muhasebe meslek mensuplarının karşılaştıkları sorunlar ve beklentiler. Mubasebe ve Finansman Dergisi, (67), 71-84. doi: 10.25095/mufad.396577.

Aytar, O. (2019), Do the ethical declarations of companies consist of similar stereotypical concepts and topics? Or are they original commitments?. Business \& Management Studies: An International Journal, 7(4), 1944-1966. doi: https://doi.org/10.15295/bmij.v7i4.1188

Aziz, H., \& Özcan, H.A. (2020). Türk hukuk sisteminde uygulamalar ile aldatıcı reklamlar. Dicle Üniversitesi Adalet Meslek Yüksekokulu Dicle Adalet Dergisi, 4(1), 1-29. https://dergipark.org.tr/en/pub/duamydad/issue/59431/853689.

Ball, M . (2015). Türk Ticaret Kanunu'na göre haksız rekabet kavramı ve unsurlar1. Gümrük ve Ticaret Dergisi, (5), 62-72. https://dergipark.org.tr/tr/pub/gumrukticaretdergisi/issue/53325/708775.

Biyan, Ö. (2012). Muhasebe meslek mensuplarına yönelik bir çalşsma: meslek mensuplarının demografik durumları, mesleki sorunlar1 ve değerlendirilmesi. Sosyoekonomi, 17(17), 105-134. https://dergipark.org.tr/tr/pub/sosyoekonomi/issue/21077/226923.

Creswel, C. W. (2013). Qualitative Inquiry and Research Design: Choosing Among Five Approaches. Third Edition, Sage Publication.

Dikmen, B. B. (2019). Muhasebe meslek mensuplarının mesleki deneyim sürelerine göre haksız rekabetin değerlendirilmesi: Giresun il merkezinde bir araşturma. Karadeniz Sosyal Bilimler Dergisi, 11(20), 89109. https://dergipark.org.tr/tr/pub/ksbd/issue/45826/498906.

Eryürek, G . (2020). Rusya Federasyonu kanunlannda haksiz rekabet. Türkiye Adalet Akademisi Dergisi, (43), 97-114. https://dergipark.org.tr/tr/pub/taad/issue/59539/873713.

Gürbüz, İ., \& Turhan, Ş. (2009). Türk gida sanayinin AB rekabet politikalarına uyumu. Uludağ $\begin{array}{lllll}\text { Üniversitesi Ziraat } & \text { Fakültesi } & \text { Dergisi, } & \text { 23(1), } & \text { 61-70. }\end{array}$ https://dergipark.org.tr/tr/pub/ziraatuludag/issue/16753/174175.

İmregün, O. (2005). Kara Ticareti Hukuku Dersleri (Genel Hükeümler-Ortakllklar-Kiymetli Evrak). 13.Bask1. İstanbul: Filiz Kitabevi. 
İSMMMO (2018). Hakssz Rekabetle Mücadele Kurulu Faaliyet Raporu. İstanbul: İSMMMO Yayınlan1 https://archive.ismmmo.org.tr/YAYINLAR/E_KITAP/FaaliyetRaporu2018/05_kurul_raporlari/05_ha ksiz_rekabetle_mucadele_kurulu.pdf [Erişim Tarihi: 06.07.2020].

Karabıçak, M. (2009). Uluslararası yabancı sermaye akımlarının Türkiye ekonomisinin küresel rekabet gücü üzerindeki etkileri. Süleyman Demirel Üniversitesi İktisadi ve İdari Bilimler Fakültesi Dergisi, 14 (1), 137-149. https://dergipark.org.tr/tr/pub/sduiibfd/issue/20831/223141.

Karahan, A. (2014). Kamu işletmelerinin rekabet gücü analizi ve ulaştırma sektörü örneği. Maliye ve Finans Yarlarl, (102), 23-42. doi: 10.33203/mfy.519259.

Karakaya, G., \& Biçer, A. (2020). Muhasebe meslek mensuplarının haksız rekabet algılarının analitik hiyerarşi süreci yöntemi ile değerlendirilmesi. İsletme Araştırmalar Dergisi, 12(2), 1149-1158. https://doi.org/10.20491/isarder.2020.902.

Kısakürek, M., \& Akarsu, A. (2016). Muhasebecilik mesleğinde haksız rekabet olgusu: Sivas ilinde bir araşurma. Atatürk Üniversitesi Sosyal Bilimler Enstitüsü Dergisi, (20)2, 647-664. https://dergipark.org.tr/tr/pub/ataunisosbil/issue/26968/283474.

Kurnaz, N., Altunal, I., \& Özbek, A. (2016). Haksız rekabeti önleme açısından TÜRMOB e-Birlik yazılımı hakkında meslek mensuplarının değerlendirmeleri üzerine ampirik bir çalışma. Mali Çöæư̈m, (135), 13-29.

Ömürbek, V., \& Türkoğlu, T. (2013). Muhasebe meslek mensupları arasında yaşanan haksız rekabet üzerine bir araştırma. Bahkesir Üniversitesi Sosyal Bilimler Enstitüsü Dergisi, 16(30), 115-149. https://dergipark.org.tr/tr/pub/baunsobed/issue/50175/645683.

Öz, M. (2020). Ürün ve Ambalaj Kararlarnda Etik: Ambalaja Yönelik Müsteri Şikayetlerinin Değerlendirilmesi, Ankara: Gazi Kitapevi.

Özel, C.., \& Özdemir, S.S. (2017). Türk hukukunda haksız rekabete ilişkin düzenlemeler, D.E.Ü. Hukuk Fakültesi Dergisi, Prof. Dr. Şeref ERTAŞ'a Armağan, (19), Özel Sayl, 189-206.

Öztürkler, M. (2016). Rekabete aykumlıklarn özel bukuk alanindaki sonuçlar ve rekabete aykemllktan dolayn uğranılan zararn tażmini. Yayınlamlanmamış Doktora Tezi, İstanbul Kültür Üniversitesi Sosyal Bilimler Enstitüsü Ana Bilim Dalı: Hukuk-Özel Hukuk Programı, İstanbul.

Pınar, H . (2012). Reklam ve satıs yöntemlerine ilişkin haksız rekabet hâlleri. Marmara Üniversitesi Hukuk Fakültesi Hukuk Araştrrmalar Dergisi, 6102 Saynh Yeni Türk. Ticaret Kanunu'nu Beklerken, (10-11-12 Mayıs 2012 Semposyum Özel Sayısı), 129-156. https://dergipark.org.tr/tr/pub/maruhad/issue/48277/614396.

Sabır, H . (2013). Küreselleşen dünyada rekabet politikası ve gelişmekte olan ülkeler. Marmara Üniversitesi Siyasal Bilimler Dergisi, 1(1), 121-133. https://dergipark.org.tr/tr/pub/marusbd/issue/289/1352.

Selçuk, A. G., Güneri, S., \& Arabacı, T. (2016). Basın yayın sektöründe rekabet stratejileri ve performans arasındaki ilişki: uluslararası ve yerel dergilerde bir inceleme. Toros Üniversitesi İ̈BF Sosyal Bilimler Dergisi, 3(5), 201-212. https://dergipark.org.tr/tr/pub/iisbf/issue/24455/259167.

Serbest Muhasebeci Mali Müşavirlik ve Yeminli Mali Müşavirlik Mesleklerine İlisskin Haksız Rekabet ve Reklam Yasağ1 Yönetmeliği, (2007, 21 Kasım). Resmi Gazete (Say1: 26707) Erişim Adresi: https://www.resmigazete.gov.tr/eskiler/2007/11/20071121-6.htm. [Erişim Tarihi: 09.11.2020].

Şendurur, U., \& Çelik, Y. (2020). Muhasebe meslek mensuplarının karşılaştı̆̆ı sorunlar ve beklentileri: Muş ve Ağr1 illeri örneği. Mubasebe ve Vergi Uygulamalarn Dergisi, 13(1), 25-50. doi: 10.29067/muvu.568083.

Türk Ticaret Kanunu, (2011, 14 Şubat). Resmi Gaz̨ete (Sayl: 27846). Erişim Adresi: https://www.resmigazete.gov.tr/eskiler/2011/02/20110214-1-1.htm [Erişim Tarihi: 23.05.2020]

Yıldırım, A., \& Şimşek, H. (2011). Sosyal Bilimlerde Nitel Araștırma Yöntemleri. Ankara: Seçkin Yayıncılık.

Yücel, R., \& Kartal, C. (2014). Muhasebecilerin mesleki uygulamalarındaki etik algılarına ilişkin bir araşturma. Kirkkeale Üniversitesi Sosyal Bilimler Dergisi, 4(2), 123-148. https://dergipark.org.tr/tr/pub/kusbd/issue/19379/205587. 